\title{
Volatile Chalcophile Elements in Native Sulfur from a Submarine Hydrothermal System at Kueishantao, Offshore NE Taiwan
}

\author{
Ming-Zhen Yu ${ }^{1}\left(\mathbb{D}\right.$, Xue-Gang Chen ${ }^{1, *}{ }^{-}$, Dieter Garbe-Schönberg ${ }^{2}\left(\mathbb{D}\right.$, Ying $\mathrm{Ye}^{1}$ and \\ Chen-Tung Arthur Chen ${ }^{3}$ \\ 1 Ocean College, Zhejiang University, Zhoushan 316021, China; yumzh3@163.com (M.-Z.Y.); \\ gsyeying@zju.edu.cn (Y.Y.) \\ 2 Institut für Geowissenschaften, Christian-Albrechts- Universität zu Kiel, 24118 Kiel, Germany; \\ dieter.garbe-schoenberg@ifg.uni-kiel.de \\ 3 Institute of Marine Geology and Chemistry, National Sun Yat-Sen University, Kaohsiung 80424, Taiwan; \\ ctchen@mail.nsysu.edu.tw \\ * Correspondence: chenxg83@zju.edu.cn; Tel.: +86-580-2092326; Fax: +86-580-2092891
}

Received: 9 March 2019; Accepted: 18 April 2019; Published: 21 April 2019

\begin{abstract}
We analyzed sulfur isotopes, trace elements and chalcophile elements $(\mathrm{Se}, \mathrm{Te}, \mathrm{As}, \mathrm{Sb}$, and $\mathrm{Hg}$ ) in the native sulfur matrix from the Kueishantao hydrothermal system and conducted a systematic micro-analytical investigation. The sulfur matrix lacked all measured metals (e.g., $\mathrm{Fe}, \mathrm{Cu}$ ) and rare earth elements (REEs) while being significantly enriched in Te, As, Se (750-1500 ppm), Sb (around $100 \mathrm{ppm}$ ) and some $\mathrm{Hg}$. The $\delta^{34} \mathrm{~S}$ data $(0.2-2.4 \%$ o) suggest a magmatic source leached from igneous rocks and a small contribution of seawater sulfates to the sulfur in hydrothermal deposits. Correlations between $\mathrm{Te}, \mathrm{As}, \mathrm{Sb}$, and $\mathrm{S}\left(r^{2}=0.30-0.61\right)$ indicate that these elements behave coherently in magmatic-hydrothermal processes. The enrichment factors and content ratios of these elements demonstrate their abundance in the sulfur matrix and minor fractionation after being partitioned into the metallic melt and forming a separate vapor phase to transport. Our study focuses on the native sulfur matrix in a shallow-water volcanic hydrothermal system, to which relatively little attention has previously been paid. This will expand our understanding of hydrothermal precipitates. The study of volatile chalcophile elements in the matrix will provide significant information about their sources, distributions and other geochemical behaviors in magmatic-hydrothermal processes and help to understand the Kueishantao hydrothermal circulation better.
\end{abstract}

Keywords: chalcophile elements; native sulfur; magmatic degassing; seafloor hydrothermal system

\section{Introduction}

According to their positions in the periodic table of elements, S, Se, and Te (Group VIA elements) and As and Sb (Group VA elements), should have similar physicochemical properties, and all these elements are classified as volatile chalcophile elements according to Goldschmidt's classification [1]. These chalcophile elements are often used as indicators for platinum-group element (PGE) mineralization since they are essential ligands for noble metals [2]. The abundance of these elements in the mantle could also be indicative of several planetary processes such as the formation of the Earth's core and the Late Veneer process, meaning the late accretion of asteroidal or cometary material to terrestrial planets [3-5]. Moreover, studying the geochemical behavior of these chalcophile elements in hydrothermal deposits could facilitate a greater understanding of the magmatic-hydrothermal processes that occur in seafloor hydrothermal systems [6-8]. Notably, the distributions and concentrations of chalcophile elements in arc-related hydrothermal deposits and systems can be used for deciphering 
provenance, indicating magmatic-hydrothermal processes such as fluid-rock interaction and mineral precipitation during the ascent of hydrothermal fluids from the mantle to the seafloor, and reflecting the physicochemical conditions of the hydrothermal system [9-12].

In seafloor hydrothermal deposits, volatile chalcophile elements $\mathrm{Se}, \mathrm{Te}, \mathrm{As}$, and $\mathrm{Sb}$ usually occur in sulfides as substitutes for sulfur $[13,14]$ and can be enriched or depleted relative to the mantle. A large number of previous studies have been concentrated on hydrothermal sulfides and sulfates, for example, sulfides from the Lau Basin and East Pacific Rise (EPR) at $13^{\circ} \mathrm{N}$ are enriched in As and Se but depleted in Te and Sb; sulfides from Manus Basin are enriched in As and Sb; sulfates from Kulo Lasi caldera are depleted in As, Se and Sb [15-18]. However, we have paid attention to the native sulfur in hydrothermal precipitates, which could reflect the magmatic processes more directly during the hydrothermal circulation in volcanic hydrothermal systems. Some researchers have reported the chalcophile elements in native sulfur and volcanic gases in hydrothermal systems. Kim et al., (2011) [19] reported low concentrations of Se $(2.3 \mathrm{ppm})$ and Te $(6.5 \mathrm{ppm})$ in a hydrothermal sulfur chimney from the northeastern Lau spreading center, while a study conducted by de Ronde et al., (2015) [20] reported Se values $>1000 \mathrm{ppm}, \mathrm{Te}>500 \mathrm{ppm}$, As $>1500 \mathrm{ppm}$ and $\mathrm{Sb}>120 \mathrm{ppm}$ for native sulfur samples from seafloor "crater lakes" of the Mariana and Kermadec arcs. At the Kilauea volcano, Hawaii, USA, the eruptive gas and native sulfur contain large amounts of $\mathrm{Se}, \mathrm{Te}$, and As that are thought to originate from magma degassing [21].

Despite these reports, the geochemical behavior of these volatile chalcophile elements in a pure native sulfur matrix in hydrothermal systems remains unclear due to the insufficient quantity of high-quality systematic data. In this study, we discovered abundant $\mathrm{Se}, \mathrm{Te}, \mathrm{As}, \mathrm{Sb}$, and some $\mathrm{Hg}$ associated with native sulfur from the Kueishantao hydrothermal area, offshore NE Taiwan. These elements are presented in the sulfur matrix rather than in sulfide inclusions as shown by high spatial resolution laser ablation inductively coupled plasma mass spectrometry (LA-ICPMS). In addition, metallic elements and S isotopes were detected in the hydrothermal native sulfur. This data allows for a systematic investigation of the sources, distributions and fractionation behaviors of chalcophile elements and sulfur in magmatic-hydrothermal processes. Not only does this expand the understanding of the Kueishantao hydrothermal system, it further encourages additional research on native sulfur inclusions or on sulfur precipitates in other hydrothermal systems.

\section{Samples and Analytical Methods}

\subsection{Geological Setting}

The Kueishantao hydrothermal field is located offshore NE Taiwan, within $1 \mathrm{~km}$ southeast of the Kueishantao islet $\left(121^{\circ} 55^{\prime} \mathrm{E}, 24^{\circ} 50^{\prime} \mathrm{N}\right)$ (Figure 1). It is also situated in a junction between the Okinawa Trough and the Philippine Plate. The Okinawa Trough which is a typical back-arc basin at a young stage of evolution was initiated through the subduction of the Philippine Sea Plate underneath the Eurasian Plate and extends from SW Kyushu to NE Taiwan [22]. Extension of the Okinawa Trough is still ongoing and has resulted in significant tectonic-magmatic activity including the formation of a hydrothermal system near the Kueishantao islet $\left(121^{\circ} 55^{\prime} \mathrm{E}, 24^{\circ} 50^{\prime} \mathrm{N}\right.$; Figure $\left.1 \mathrm{~b}\right)$, a Holocene-aged volcanic island resulting from an eruption approximately 7000 years ago [23]. This tide-influenced hydrothermal system comprises of more than 30 hydrothermal vents at depths between $10 \mathrm{~m}$ and $30 \mathrm{~m}$ [24]. Vent fluid characteristics allow relatively high-temperature vents $\left(78\right.$ to $\left.116^{\circ} \mathrm{C}\right)$ and an average fluid flux of about $150 \mathrm{t} / \mathrm{h}^{-1}$ to be distinguished from low-temperature vents $\left(30-65^{\circ} \mathrm{C}\right)$ with an average fluid flux of less than $7 \mathrm{t} / \mathrm{h}^{-1}[25,26]$. 
(a)

(b)
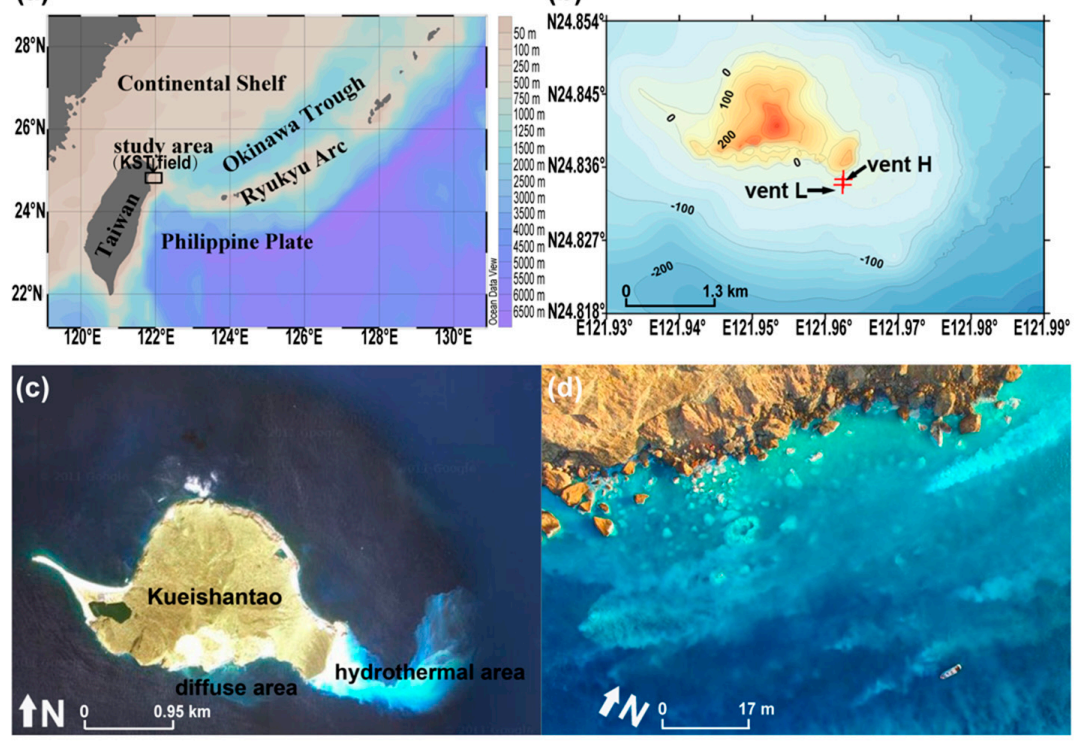

Figure 1. Geological setting of the Kueishantao hydrothermal field. (a) Geological setting of Kueishantao (KST) area at the southwest end of the Okinawa Trough. Box outlined in black is area given in (b); (b) Bathymetric map of KST field. The red "+" symbols show the positions of the white vent and yellow vent, respectively; (c) Satellite image of Kueishantao island and the KST hydrothermal field with diffuse and focused fluid areas; (d) Aerial view of the KST sampling area (note ship in the lower right corner; courtesy of M. Lebrato).

\subsection{Sample Collection and Description}

The native sulfur aggregates are mainly distributed around the relatively high-temperature vent (vent $\mathrm{H}$ ) in the Kueishantao hydrothermal system. We collected about $1 \mathrm{~kg}$ of sulfur samples in the hydrothermal precipitates around the chimneys from vent $\mathrm{H}$ via scuba divers (Figure 1). Here, vent fluid temperatures $\left(78-116^{\circ} \mathrm{C}\right.$ ) are near the boiling point of seawater at the vent depth of $\sim 13 \mathrm{~m}$ (about $105^{\circ} \mathrm{C}$ ) [27]. The $\mathrm{pH}$ of the vent fluid ranges between 1.5 and 6.3 [26]. Yellow-colored hydrothermal fluid continuously emanated from the vent chimney forming sulfur-rich aggregates at the seafloor around the vent $[26,28,29]$.

Native sulfur aggregates in the hydrothermal precipitates at Kueishantao mainly consisted of yellow "chips" with diameters of about $2 \mathrm{~mm}$, yellow spheres of about $2 \mathrm{~mm}$, gray spheres of about 1.6 $\mathrm{mm}$, and as impurities within andesite fragments (Figure 2). Based on our analyses as well as those of previous studies [26,30], the yellow and gray spheres and yellow chips were all dominated by sulfur. The color difference may be attributed to their different polymorphs and modifications of sulfur [20,31], or different concentrations of impurities such as Se and volcanic mixtures [32]. The fragments of andesite originated from volcaniclastics and andesitic bedrock in the Kueishantao area [33].
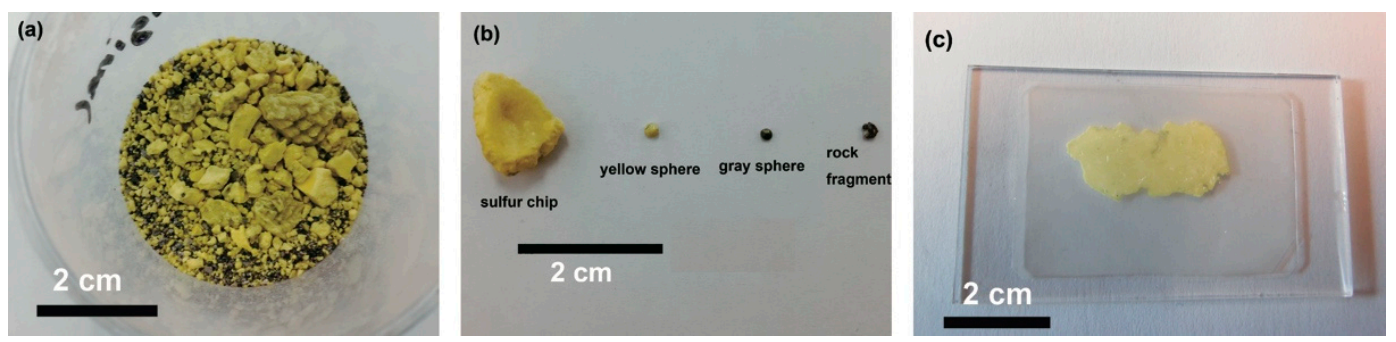

Figure 2. Photographs of native sulfur. (a) Native sulfur sample collected from a high-temperature vent; (b) Different sulfur aggregates and a rock fragment enclosed in native sulfur that were picked from the native sulfur samples; (c) Thin section of a sulfur chip. 


\subsection{Analytical Methods}

Prior to LA-ICPMS analysis and optical microscopy studies, the grains of native sulfur were washed thoroughly with distilled water and dried overnight in a temperature-controlled oven at $105^{\circ} \mathrm{C}$. Subsequently, the yellow sulfur spheres and sulfur chips were separated from the remainder of the sample using plastic tweezers. For the LA-ICPMS analyses and microscopy work, aliquots of the sulfur chips were mounted on glass slides using a polymer resin, then polished. We made three slides, on each of which the thickness of sulfur samples was $0.3 \mathrm{~mm}$.

For sulfur isotope measurements, the powdered sulfur chips (30-200 $\mu \mathrm{g}$ ) were homogeneously mixed with an equal amount of vanadium pentoxide $\left(\mathrm{V}_{2} \mathrm{O}_{5}\right)$ and transferred into capsules. Sulfur dioxide $\left(\mathrm{SO}_{2}\right)$ was generated in an elemental analyzer via flash combustion, chromatographically purified, and transferred to the mass-spectrometer via a stream of helium [14]. Isotope measurements were performed in duplicate by the elemental analyzer isotope ratio mass spectrometry (EA-IRMS) method, using a Thermo Finnigan Delta Plus mass spectrometer (ThermoFisher, Waltham, MA, USA). Results are reported in conventional $\delta^{34} S$ notation relative to the Vienna Canon Diablo Troilite (V-CDT). Reproducibility determined by replicate analyses was generally better than $\pm 0.3 \%$ o ( $1 \sigma$ level) for reference samples. Accuracy was monitored using lab standards (silver sulfide $\mathrm{Ag}_{2} \mathrm{~S}$ ) and international reference materials (e.g., IAEA S1, S2, and S3).

Optical microscopy was performed using a Zeiss Axiophot microscope with a Leica DFC295 camera (Leica, Wetzlar, Germany).

The LA-ICPMS analyses were conducted on an Agilent 7500s quadrupole ICPMS coupled with a GeolasPro $193 \mathrm{~nm}$ excimer laser ablation system (Coherent, Santa Clara, CA, USA) at the Marine Climate Research ICPMS Laboratory of Christian-Albrechts-Universitaet Kiel. The forward power of ICPMS is $1500 \mathrm{~W}$. Helium $\left(1.0 \mathrm{~L} / \mathrm{min}^{-1}\right)$ and hydrogen $\left(14 \mathrm{~mL} / \mathrm{min}^{-1}\right)$ were used as carrier gases with a residence time of $10 \mathrm{~ms}$. The laser wavelength and frequency were $193 \mathrm{~nm}$ and $10 \mathrm{~Hz}$ respectively. The analyses began with approximately $20 \mathrm{~s}$ background measurement followed by 20-22 s sample ablation and signal measurement $[34,35]$. Thirty-four spots were ablated in our samples using a laser spot size of $50 \mu \mathrm{m}$ in diameter at $3.5 \mathrm{~J} / \mathrm{cm}^{-2}$. Accuracy and precision of the analyses were controlled by using blank reference materials (AGV-2 and JCP-1) and tests replicated [36]. The standard error of the measurement was less than 5\%. Signal integration and analysis were done using the GLITTER software package (Macquarie Research, Ltd., London, UK). The following methods were used to calculate the elemental content in the sample [35,37]:

(1) The isotope counts-per-second (CPS) abundance of each element was calculated by subtracting the background value from the signal value of the isotope;

(2) Assuming that the isotope abundance of the element in the sample is the same as its natural abundance, the CPS value of the element was calculated by the following formula:

$$
\text { element }_{\mathrm{CPS}}=\text { isotope }_{\mathrm{CPS}} / \text { isotope }_{\text {na }}
$$

where element ${ }_{C P S}$ is the CPS value of the element in the sample, isotope $e_{C P S}$ is the isotope CPS value of the element in the sample, isotope ${ }_{n a}$ is the natural isotope abundance of the element;

(3) Assuming that the fractionation of elements during the tests could be ignored and the relative ablation yield is comparable for all elements, the element concentration in the sample was calculated by the following formula:

$$
C_{e l}=\text { element }_{C P S} / \sum \text { element }_{C P S}
$$

where $C_{e l}$ is the element concentration in the sample, Eelement ${ }_{C P S}$ is the total CPS values of all the tested elements in the sample. 
The detection limits of the elements are as follows: $\mathrm{Al}=5 \times 10^{-6} ; \mathrm{S}=7.8 \%$; $\mathrm{Mn}=5 \times 10^{-6}$; $\mathrm{Fe}=10 \times 10^{-6} ; \mathrm{Co}, \mathrm{Ni}, \mathrm{Cu}$ and $\mathrm{Zn}=5 \times 10^{-6} ; \mathrm{As}=6 \times 10^{-6} ; \mathrm{Se}=2 \times 10^{-5} ; \mathrm{Sb}=4 \times 10^{-6} ; \mathrm{Te}=3 \times 10^{-5}$; $\mathrm{Ba}=3 \times 10^{-6} ; \mathrm{La}$ and $\mathrm{Ce}=2 \times 10^{-6} ; \mathrm{Hg}=10^{-5} ; \mathrm{Pb}=5 \times 10^{-6}$.

\section{Results}

\subsection{Optical Microscopy}

Sulfur aggregates were studied using both reflected and transmitted light microscopy with representative microphotographs shown in Figure 3. The layered sulfur matrix was yellowish, but a little darker in the overlapping part of it. The lack of homogeneity is clearly evident by the numerous, irregularly dispersed, solid inclusions hosted in the native sulfur matrix (Figure 3a,c). Most inclusions are globular grains of 5-30 $\mu \mathrm{m}$ diameter and gray-black. These inclusions may be Fe-sulfides, tellurides or selenides that formed from precursory droplets or microcrystal precipitates of hydrothermal fluid, however further micro-characterization is needed. Some inclusions form discontinuous "veinlets" with a width of about $10 \mu \mathrm{m}$ and a length of 50-200 $\mu \mathrm{m}$.
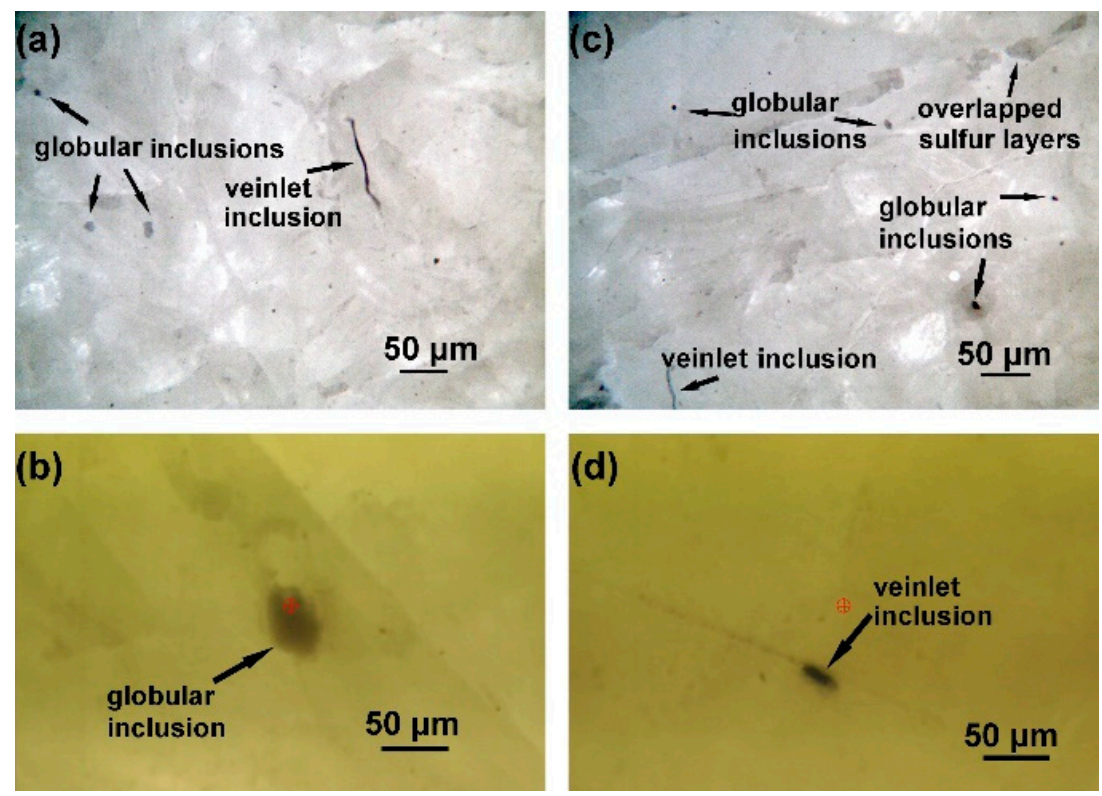

Figure 3. Microscopy images of native sulfur, and inclusions, from a moderate temperature (about $100{ }^{\circ} \mathrm{C}$ ) vent at the Kueishantao hydrothermal area. (a,c) are transmitted light microscopy images; $(\mathbf{b}, \mathbf{d})$ are reflected light microscopy images. The red circles with crosshairs shown in $(\mathbf{b}, \mathbf{d})$ represent inclusions found in samples.

\subsection{LA-ICPMS}

LA-ICPMS results for the native sulfur from the Kueishantao hydrothermal area are compiled in Table 1 . The sulfur contents vary between $99.4 \%$ and $99.7 \%$ for all 34 spots; similar to those derived from a native sulfur aggregate and a sulfur chimney previously studied from this area [30,38]. In addition to sulfur, the contents of chalcophile elements Se, Te and As for most spots are greater than $900 \mathrm{ppm}$ : Se, 1189-1587 ppm (average 1410 ppm), Te, 848-1286 ppm (average 1044 ppm), and As, 515-1593 ppm (average $1067 \mathrm{ppm}$ ). Lesser concentrations of $\mathrm{Sb}$ (42-219 ppm) and $\mathrm{Hg}$ (19-90 ppm) were also measured in the sulfur matrix.

The Se and Te contents determined in this study are significantly higher than concentrations measured in native sulfur or sulfide from other hydrothermal fields, such as the Lau Basin, the East Pacific Rise, the Mariana arc and the Izu-Bonin arc (Table 2). At these locations, both Se and Te contents are generally below 100 ppm. However, the highest Se concentration (1095 ppm) was measured in 
sulfides from the EPR at $13^{\circ} \mathrm{N}$ which could be attributed to the substitution of Se for $\mathrm{S}$ in chalcopyrite in that hydrothermal system [16].

The As and $\mathrm{Sb}$ concentrations measured in this study are generally higher than reported from native sulfur or sulfides in most other hydrothermal fields (Table 2). But sulfides studied from the Izu-Bonin arc including the Sunrise hydrothermal area of Myojin Knoll and Suiyo Seamount, and Kuroko deposits show substantially higher As and Sb concentrations, which has been attributed to the abundant presence of iron sulfides [39]. Calculated endmember seafloor hydrothermal fluids and volcanic gases typically have Se, Te, As, and Sb concentrations below $100 \mathrm{ppb}$ [27].

In addition to these volatile chalcophile elements, a few other elements were detected in the native sulfur matrix from the Kueishantao hydrothermal area. Low concentrations of $\mathrm{Al}(\leq 60 \mathrm{ppm}), \mathrm{Fe}$ $(\leq 300 \mathrm{ppm})$, and $\mathrm{Cu}(5-12 \mathrm{ppm})$ were measured in small inclusions. Other metals such as $\mathrm{Mn}, \mathrm{Co}, \mathrm{Ni}$, $\mathrm{Zn}, \mathrm{Ba}$, and $\mathrm{Pb}$ were generally below their detection limits (Table 1). Rare earth elements (REEs) were detected in only one of the analyzed samples in the sulfur matrix (sample 006, Table 1).

\subsection{Sulfur Isotopes}

Sulfur isotope results are presented in Table 3. The total range of $\delta^{34} S$ values for our native sulfur samples at the Kueishantao hydrothermal area is from $0.2 \%$ o to $2.4 \%$. These values are almost identical to data for a Kueishantao sulfur chimney reported in previous studies in which a mantle origin was suggested by the researchers [26,38]. By contrast, $\delta^{34} \mathrm{~S}$ values of our samples are much lower than that of Kueishantao hydrothermal sulfides (22.4-31.3\%o) and sulfates (16.3-19.7\%o), which are close to seawater $\delta^{34} \mathrm{~S}$ value $\left(20.9 \%\right.$ ) $[40,41]$. When compared to other hydrothermal fields (Table 3), the $\delta^{34} \mathrm{~S}$ values of Kueishantao native sulfur are significantly higher than that of Mariana Arc native sulfur $(-9.0 \%$ o to $-6.2 \%$ o) and Manus Basin native sulfur $(-7.4 \%$ o to $-0.3 \%$ o $)[18,20]$. However, the spread of $\delta^{34} \mathrm{~S}$ values of our samples overlaps with a large portion of the data for hydrothermal sulfides at Lucky Strike (Table 3) which has indicated a dual source for sulfur: magmatic sulfur and seawater sulfate [14]. 
Table 1. Laser ablation inductively coupled plasma mass spectrometry (LA-ICPMS) results for the sulfur matrix of the native sulfur aggregates from Kueishantao area (all in ppm except for sulfur).

\begin{tabular}{|c|c|c|c|c|c|c|c|c|c|c|c|c|c|c|c|c|c|}
\hline Sample & Al & S (\%) & Mn & $\mathrm{Fe}$ & Co & $\mathrm{Ni}$ & $\mathrm{Cu}$ & $\mathrm{Zn}$ & As & Se & $\mathrm{Sb}$ & $\mathrm{Te}$ & Ba & La & $\mathrm{Ce}$ & $\mathrm{Hg}$ & $\mathbf{P b}$ \\
\hline 902 & b.d.l. & 99.6 & b.d.l. & b.d.l. & b.d.l. & b.d.l. & b.d.l. & b.d.l. & 986 & 1483 & 94 & 1070 & b.d.l. & b.d.l. & n.d. & 35 & b.d.l. \\
\hline 907 & b.d.l. & 99.6 & n.d. & 226 & b.d.l. & b.d.l. & b.d.l. & b.d.l. & 1027 & 1489 & 100 & 1095 & n.d. & n.d. & n.d. & 34 & b.d.l. \\
\hline 908 & 99 & 99.5 & 6 & 170 & b.d.l. & b.d.l. & b.d.l. & b.d.l. & 1475 & 1486 & 139 & 1154 & b.d.l. & n.d. & b.d.l. & 50 & b.d.l. \\
\hline 909 & b.d.l. & 99.6 & b.d.l. & b.d.l. & n.d. & b.d.l. & b.d.l. & b.d.l. & 1094 & 1445 & 104 & 1065 & b.d.l. & n.d. & n.d. & 36 & b.d.l. \\
\hline 910 & b.d.l. & 99.6 & n.d. & b.d.l. & b.d.l. & b.d.l. & b.d.l. & b.d.l. & 1037 & 1393 & 100 & 1032 & b.d.l. & b.d.l. & b.d.l. & 37 & b.d.l. \\
\hline 911 & b.d.l. & 99.6 & n.d. & b.d.l. & b.d.l. & b.d.l. & b.d.l. & b.d.l. & 996 & 1403 & 94 & 1018 & b.d.l. & b.d.l. & n.d. & 37 & b.d.l. \\
\hline 912 & b.d.l. & 99.6 & b.d.l. & 29 & b.d.l. & n.d. & b.d.l. & b.d.l. & 965 & 1500 & 90 & 1034 & b.d.l. & b.d.l. & b.d.l. & 36 & b.d.l. \\
\hline 913 & b.d.l. & 99.6 & b.d.l. & b.d.l. & b.d.l. & b.d.l. & b.d.l. & b.d.l. & 907 & 1474 & 84 & 1013 & b.d.l. & n.d. & b.d.l. & 33 & b.d.l. \\
\hline 914 & b.d.l. & 99.6 & b.d.l. & 11 & b.d.l. & b.d.l. & b.d.l. & b.d.l. & 1096 & 1462 & 102 & 1059 & b.d.l. & n.d. & n.d. & 38 & b.d.l. \\
\hline 915 & b.d.l. & 99.6 & b.d.l. & 33 & b.d.l. & b.d.l. & b.d.1. & b.d.l. & 1014 & 1486 & 96 & 1053 & n.d. & n.d. & n.d. & 35 & b.d.l. \\
\hline 916 & b.d.l. & 99.7 & n.d. & b.d.l. & n.d. & b.d.l. & b.d.l. & b.d.l. & 756 & 1489 & 68 & 970 & n.d. & n.d. & b.d.l. & 25 & b.d.l. \\
\hline 917 & b.d.l. & 99.6 & b.d.l. & 186 & b.d.l. & b.d.l. & b.d.l. & b.d.l. & 762 & 1462 & 71 & 985 & b.d.l. & n.d. & n.d. & 28 & b.d.l. \\
\hline 918 & b.d.l. & 99.7 & n.d. & 23 & b.d.l. & b.d.l. & b.d.l. & b.d.l. & 827 & 1394 & 81 & 961 & b.d.l. & b.d.l. & n.d. & 34 & b.d.l. \\
\hline 919 & b.d.l. & 99.6 & n.d. & 11 & b.d.l. & b.d.l. & b.d.l. & b.d.l. & 907 & 1450 & 84 & 1014 & b.d.l. & n.d. & n.d. & 38 & b.d.l. \\
\hline 920 & b.d.l. & 99.6 & b.d.l. & 606 & b.d.l. & b.d.l. & b.d.l. & b.d.l. & 1065 & 1502 & 102 & 1115 & b.d.l. & b.d.l. & b.d.l. & 42 & b.d.l. \\
\hline 921 & b.d.l. & 99.6 & n.d. & 23 & b.d.l. & b.d.l. & b.d.l. & b.d.l. & 1218 & 1356 & 113 & 1048 & n.d. & b.d.l. & n.d. & 58 & b.d.l. \\
\hline 922 & b.d.l. & 99.6 & n.d. & 29 & n.d. & b.d.l. & b.d.l. & b.d.l. & 1593 & 1400 & 148 & 1111 & b.d.l. & b.d.l. & n.d. & 76 & n.d. \\
\hline 923 & b.d.l. & 99.6 & n.d. & b.d.l. & b.d.l. & n.d. & b.d.l. & b.d.l. & 1077 & 1410 & 95 & 1020 & n.d. & n.d. & b.d.l. & 41 & n.d. \\
\hline 924 & 56 & 99.5 & 8 & 1327 & b.d.l. & b.d.l. & b.d.l. & b.d.l. & 846 & 1448 & 78 & 1009 & b.d.l. & b.d.l. & b.d.l. & 31 & b.d.l. \\
\hline 925 & b.d.l. & 99.6 & n.d. & 17 & b.d.l. & b.d.l. & b.d.l. & b.d.l. & 1190 & 1305 & 108 & 983 & b.d.l. & b.d.l. & b.d.l. & 43 & b.d.l. \\
\hline 926 & b.d.l. & 99.6 & n.d. & 22 & n.d. & b.d.l. & b.d.l. & b.d.l. & 1159 & 1386 & 105 & 1004 & b.d.l. & b.d.l. & b.d.l. & 42 & b.d.l. \\
\hline 927 & b.d.l. & 99.6 & n.d. & b.d.l. & b.d.l. & b.d.l. & 6 & b.d.l. & 1175 & 1428 & 102 & 1023 & n.d. & n.d. & b.d.l. & 44 & b.d.l. \\
\hline 928 & b.d.l. & 99.6 & n.d. & 23 & n.d. & b.d.l. & 12 & b.d.l. & 957 & 1406 & 84 & 1011 & b.d.l. & n.d. & n.d. & 35 & b.d.l. \\
\hline 929 & b.d.l. & 99.6 & n.d. & b.d.l. & b.d.l. & b.d.l. & b.d.l. & b.d.l. & 1332 & 1396 & 116 & 1028 & b.d.l. & b.d.l. & b.d.l. & 50 & b.d.l. \\
\hline 930 & 23 & 99.6 & b.d.l. & 126 & b.d.l. & b.d.l. & b.d.l. & b.d.l. & 1422 & 1323 & 136 & 1053 & b.d.l. & n.d. & b.d.l. & 51 & b.d.l. \\
\hline 931 & b.d.l. & 99.7 & n.d. & n.d. & b.d.l. & b.d.l. & b.d.l. & b.d.l. & 515 & 1303 & 42 & 848 & n.d. & n.d. & b.d.l. & 19 & b.d.l. \\
\hline 933 & 55 & 99.5 & b.d.l. & 836 & b.d.l. & b.d.l. & b.d.l. & b.d.l. & 973 & 1587 & 86 & 1153 & b.d.l. & b.d.l. & b.d.l. & 35 & b.d.l. \\
\hline 934 & 30 & 99.6 & b.d.l. & 89 & b.d.l. & b.d.l. & 5 & b.d.l. & 977 & 1383 & 90 & 983 & b.d.l. & b.d.l. & b.d.l. & 32 & b.d.l. \\
\hline 935 & b.d.l. & 99.6 & n.d. & 14 & b.d.l. & b.d.l. & b.d.l. & b.d.l. & 1312 & 1408 & 119 & 966 & b.d.l. & n.d. & n.d. & 45 & b.d.l. \\
\hline 936 & b.d.l. & 99.7 & n.d. & 41 & b.d.l. & 6 & 6 & b.d.l. & 1007 & 1293 & 86 & 922 & b.d.l. & n.d. & n.d. & 34 & b.d.l. \\
\hline 937 & b.d.l. & 99.6 & n.d. & 62 & n.d. & b.d.l. & 8 & b.d.l. & 1252 & 1360 & 110 & 1048 & b.d.l. & n.d. & n.d. & 43 & b.d.l. \\
\hline 004 & 31 & 99.4 & 9 & 2103 & 5 & b.d.l. & b.d.l. & b.d.l. & 1067 & 1189 & 132 & 1150 & b.d.l. & b.d.l. & b.d.l. & 90 & b.d.l. \\
\hline 005 & 12 & 99.6 & b.d.l. & 26 & b.d.l. & 86 & b.d.l. & b.d.l. & 1151 & 1237 & 130 & 1196 & b.d.l. & n.d. & n.d. & 74 & n.d. \\
\hline 006 & 8 & 99.5 & b.d.l. & n.d. & 7 & b.d.l. & b.d.l. & 9 & 1138 & 1394 & 219 & 1286 & b.d.l. & 5.0 & 50.5 & 72 & b.d.l. \\
\hline
\end{tabular}

b.d.l.: below detection limit. n.d. no signal was detected. 
Table 2. Comparison of $\mathrm{S}, \mathrm{Se}, \mathrm{Te}, \mathrm{As}, \mathrm{Sb}$ data from this study with published data. The mean values are shown in brackets.

\begin{tabular}{|c|c|c|c|c|c|c|}
\hline Samples & $\mathrm{S}(\%)$ & As (ppm) & Se (ppm) & Te (ppm) & $\mathrm{Sb}(\mathrm{ppm})$ & Data Source \\
\hline native sulfur matrix from Kueishantao area & 99.54-99.67 (99.63) & 756-1475(995) & 1389-1496(1454) & $961-1155(1041)$ & 70-143(97) & this study \\
\hline native sulfur chimney from Kueishantao area & $98.63-99.13(98.91)$ & $360-890(585)$ & $120-220(183)$ & b.d.l. & n.d. & [42] \\
\hline Mariana Arc native sulfur & $51.1-99.5(82.6)$ & $<0.5-1520(348)$ & $22-1140(415)$ & $1.6->500(155)$ & $<0.1-128(25)$ & [20] \\
\hline Lau basin molten sulfur & $13.74-19.93(16.9)$ & $252-641(421)$ & $4.4-6.3(5.4)$ & $0.5-3.3(1.8)$ & $22.0-34.3(28.2)$ & \\
\hline Lau basin chimney & $13.34-18.38(16.7)$ & $160-723(350)$ & $1.3-4.2(2.3)$ & $5.3-7.9(6.5)$ & $3.3-23.1(14.2)$ & [19] \\
\hline Lau basin sulfide & $18.21-43.64(30.12)$ & $473-4586(2213)$ & $0-22(8)$ & n.d. & $25-86(51)$ & [43] \\
\hline East Pacific Rise (EPR) $13^{\circ} \mathrm{N}$ sulfide & $25.5-51.0(35.12)$ & $0-1253(154)$ & $0-1095(163)$ & n.d. & n.d. & [16] \\
\hline Sunrise hydrothermal sulfide & n.d. & $360-8460(3050)$ & n.d. & $0.2-25(5.9)$ & $5.3-8020(2037)$ & \\
\hline Kuroko deposit & n.d. & $70-22,900(4348)$ & n.d. & b.d.1.-15.0 & $9-16,800(1625)$ & [39] \\
\hline Suiyo Seamount deposit & n.d. & $16-6920(2122)$ & n.d. & b.d.1. -4.3 & $2.9-1650(450)$ & \\
\hline $\begin{array}{c}\text { hydrothermally altered rocks at La Fossa } \\
\text { volcano }\end{array}$ & 6.59 & 746 & n.d. & 75 & $<5$ & [44] \\
\hline spinel lherzolites & 50-210 (98) ppm & n.d. & 1.3-63(26.1) ppb & $<2-18(11.6) \mathrm{ppb}$ & n.d. & [5] \\
\hline Harzburgites from Lherz & $0.5-10.0(2.9)$ & n.d. & $1.76-11.54(5.5)$ & $0.200-3.2(0.8)$ & n.d. & {$[3]$} \\
\hline primitive mantle sulfides & 36.4 & $0-670(30)$ & $21-280(109)$ & b.d.l. -44 & b.d.l.-146 & [45] \\
\hline primitive mantle & $250 \mathrm{ppm}$ & 0.05 & 0.075 & 0.012 & 0.14 & {$[4]$} \\
\hline $\begin{array}{l}\text { Mid-ocean ridge basalt (MORB) from active } \\
\text { spreading center }\end{array}$ & n.d. & n.d. & $103-335(204.8) \mathrm{ppb}$ & $0.97-17.3(6.95) \mathrm{ppb}$ & $2.23-74.2(16.7) \mathrm{ppb}$ & [46] \\
\hline CI Carbonaceous chondrites & 5.40 & 1.85 & 21 & 2.33 & 140 & [4] \\
\hline endmenber fluid: $21^{\circ} \mathrm{EPR}$ & $\mathrm{H}_{2} \mathrm{~S} 224-285 \mathrm{ppm}$ & $2.25-34 \mathrm{ppb}$ & $<0.05-5.7 \mathrm{ppb}$ & n.d. & n.d. & {$[27]$} \\
\hline endmenber fluid: Guaymas & $\mathrm{H}_{2} \mathrm{~S} 129-204 \mathrm{ppm}$ & $20-80 \mathrm{ppb}$ & $3-8 \mathrm{ppb}$ & n.d. & n.d. & [27] \\
\hline volcanic gas from Kilauea volcano & $9.58-12.30$ & $1.7-4.5$ & $2.5-3.2$ & $0.21-0.32$ & n.d. & [211] \\
\hline sulfur sublimates from Kilauea volcano & n.d. & $<0.5-33.0(6.5)$ & $1300-2900(1975)$ & $14-200(60)$ & n.d. & {$[21]$} \\
\hline
\end{tabular}


Table 3. Comparison of sulfur isotopic values for Kueishantao native sulfur with published data.

\begin{tabular}{ccc}
\hline Samples & $\boldsymbol{\delta}^{34} \mathbf{S}(\mathbf{V}-\mathbf{C D T} \% \mathbf{o})$ & Data Source \\
\hline Kueishantao native sulfur & $0.2-2.4$ & this study \\
Kueishantao native sulfur chimney & $-0.5-2.0$ & {$[26,38]$} \\
Kueishantao hydrothermal sulfide & $22.4-31.3$ & {$[40]$} \\
Kueishantao hydrothermal sulfate & $16.3-19.7$ & {$[20]$} \\
Mariana Arc native sulfur & $-9.0-(-6.2)$ & {$[18]$} \\
Manus Basin native sulfur & $-7.4-(-0.3)$ & {$[14]$} \\
Lucky Strike hydrothermal sulfide & $-0.5-4.6$ & {$[47]$} \\
MORB & $-0.6-0.9$ & {$[41]$} \\
seawater & 20.9 & \\
\hline
\end{tabular}

\section{Discussion}

\section{1. $\mathrm{Fe}, \mathrm{Cu}, \mathrm{Zn}$ and $\delta^{34} \mathrm{~S}$}

The paucity of metallic elements in our samples has been shown in Table 1. The contents of $\mathrm{Fe}, \mathrm{Cu}$ and $\mathrm{Zn}$ were significantly low in the native sulfur matrix at the Kueishantao hydrothermal area. However, this could not be interpreted as being due to a lack of these metal elements in the whole Kueishantao hydrothermal system since only the elements in the sulfur matrix were detected. Chen et al. (2018) [37] analyzed the inclusions in the Kueishantao native sulfur and reported high contents of Fe and $\mathrm{Cu}$ (97-870,152 ppm and 33-174,382 ppm, respectively) in the sulfur inclusions, which indicates that metallic elements tend to be enriched in the inclusions in contrast to the enrichment of chalcophile elements in the sulfur matrix.

The $\delta^{34} \mathrm{~S}$ values of our samples $(0.2-2.4 \%$ o) suggest a dual source of sulfur in Kueishantao hydrothermal precipitates: magmatic sulfur from the leaching of igneous rocks, and the contribution of seawater sulfate to the hydrothermal deposit $[14,48]$. Previous studies have suggested a magmatic input into the Kueishantao hydrothermal system based on the relatively high concentrations of $\mathrm{H}_{2} \mathrm{~S}$ and low $\mathrm{pH}$ in the hydrothermal fluids $[25,49,50]$. The range of $\delta^{34} \mathrm{~S}$ values of our samples also partly overlaps the range of magmatic values $(0 \pm 1 \%$ o $[14]$. Therefore, we suggest a contribution of a magmatic source of sulfur through leaching or other magmatic processes. However, $\delta^{34} S$ data would be expected to be negative for any magmatic source $[18,20]$ rather than the slightly positive values in this study. This could be related to a small contribution of seawater. The reduction of mixed seawater sulfate could result in a further increase in $\delta^{34} S$ values $[48,51]$ which will make the positive $\delta^{34} \mathrm{~S}$ values applicable.

\subsection{S, Se, Te, As, and Sb Systematics}

Volatile chalcophile elements ( $\mathrm{Se}, \mathrm{Te}, \mathrm{As}, \mathrm{Sb}$, and $\mathrm{Hg}$ ) are predominately enriched in the native sulfur matrix in the Kueishantao hydrothermal system. Results facilitate a reconstruction of the fractionation behavior of these elements during magmatic-hydrothermal processes. Pearson correlation analyses (SPSS, version 16.0, IBM, Armonk, NY, USA) using concentration data for S, Se, Te, As, and Sb in the samples displays a two-tailed distribution, with the significant level showing $P$ values of 0.01 (Table 4). The large absolute values of Pearson correlation coefficient (Pearson's $r$ ) shown in Table 4 and the low $P$ value (0.01) indicate that concentrations of these elements are significantly correlated with each other, particularly S, As, Sb and Te [24,52]. In sulfide deposits from the Lau Basin [43] and mantle sulfides [3,5], concentrations of As, Se, and Te increase and covary with sulfur abundances due to their comparable geochemical behavior. In the native sulfur matrix from Kueishantao, $\mathrm{Te}, \mathrm{As}$ and $\mathrm{Sb}$ show positive correlations with each other (Figure 4), suggesting their highly comparable geochemical behavior. This may be attributed to their similar chemical properties since both As and Sb belong to the VA group of elements while As and Te are diagonally adjacent elements in the periodic table. $\mathrm{Hg}$ also shows positive correlations with $\mathrm{Te}, \mathrm{As}$ and $\mathrm{Sb}$ (Figure 4) and significant amounts of $\mathrm{Hg}$ and $\mathrm{Se}$ 
(up to $50 \mathrm{ppm}$ each) can be detected around vents where native $S$ is present [53]. Se, however, exhibits relatively weak correlations with $\mathrm{As}, \mathrm{Sb}$ and $\mathrm{Te}$, indicating different fractionation behaviors between VA and VIA elements during magmatic-hydrothermal processes, such as the mixing of upward magmatic materials with infiltrating seawater or freshwater $[17,40]$. Although differences among these elements were observed, correlation systematics among $\mathrm{Se}, \mathrm{Te}, \mathrm{As}, \mathrm{Sb}, \mathrm{Hg}$ and $\mathrm{S}$ still indicate that these elements behaved rather coherently in the magmatic-hydrothermal processes that govern the Kueishantao hydrothermal system.

Table 4. Correlations among $\mathrm{S}, \mathrm{Se}, \mathrm{Te}, \mathrm{As}$ and $\mathrm{Sb}$ in the Kueishantao native sulfur matrix.

\begin{tabular}{ccccc}
\hline Element & $\mathbf{S}$ & As & Sb & Se \\
\hline $\mathrm{As}$ & -0.313 & - & - & - \\
$\mathrm{Sb}$ & $-0.512^{\mathrm{a}}$ & $0.718^{\mathrm{a}}$ & - & - \\
$\mathrm{Se}$ & -0.003 & -0.145 & -0.234 & - \\
$\mathrm{Te}$ & $-0.687^{\mathrm{a}}$ & $0.466^{\mathrm{a}}$ & $0.778^{\mathrm{a}}$ & 0.084 \\
\hline
\end{tabular}

${ }^{\text {a }}$ Significant at 0.01 probability level.
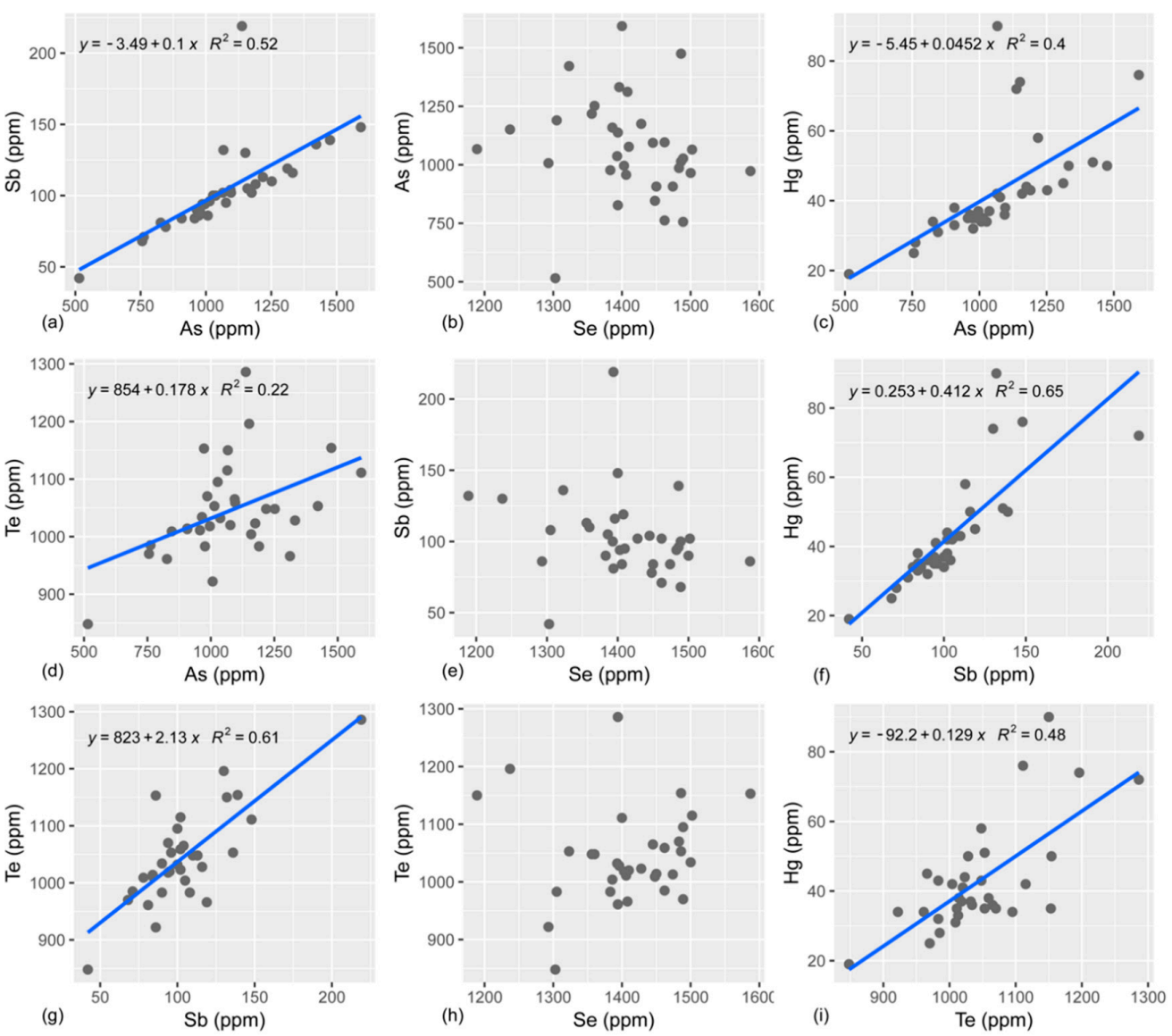

Figure 4. Correlations between concentrations of $\mathrm{As}, \mathrm{Se}, \mathrm{Te}, \mathrm{Sb}$ and $\mathrm{Hg}$ in Kueishantao native sulfur. (a) The correlation between concentrations of $\mathrm{As}$ and $\mathrm{Sb}$ in Kueishantao native sulfur; (b) The correlation between concentrations of As and Se in Kueishantao native sulfur; (c) The correlation between concentrations of As and $\mathrm{Hg}$ in Kueishantao native sulfur; (d) The correlation between concentrations of As and Te in Kueishantao native sulfur; (e) The correlation between concentrations of Se and Sb in Kueishantao native sulfur; (f) The correlation between concentrations of $\mathrm{Hg}$ and $\mathrm{Sb}$ in Kueishantao native sulfur; (g) The correlation between concentrations of Te and Sb in Kueishantao native sulfur; (h) The correlation between concentrations of Se and Te in Kueishantao native sulfur; (i) The correlation between concentrations of $\mathrm{Hg}$ and $\mathrm{Te}$ in Kueishantao native sulfur. 


\subsection{Fractionation Behavior of S, Se, and Te}

The volatile chalcophile elements $\mathrm{Se}, \mathrm{Te}, \mathrm{As}$ and $\mathrm{Sb}$ generally covary with sulfur during magmatic-hydrothermal processes, with some differences due to their distinctive geochemical behavior, such as fractionation $[45,54]$. In this study, we compared the $\mathrm{S} / \mathrm{Se}, \mathrm{Se} / \mathrm{Te}, \mathrm{Se} / \mathrm{As}$ and $\mathrm{As} / \mathrm{Sb}$ values measured for native sulfur from the Kueishantao hydrothermal area to that of native sulfur and sulfides from other hydrothermal fields and reservoirs, such as seawater, mid-ocean ridge basalt (MORB), mantle rocks and $\mathrm{CI}$ chondrites (Figure 5), in order to trace the fractionation behavior of these elements from the mantle to the seafloor.

The S/Se values in our native sulfur samples are significantly lower than that of seawater, demonstrating that contribution from seawater is quite small in our samples. However, our values are comparable to that of harzburgite, pyrolite and primitive mantle sulfide which represent an upper mantle composition. This suggests no significant fractionation of $\mathrm{S}$ and Se during magmatic processes, e.g., mantle degassing, and indicates coherent geochemical behavior of Se and $\mathrm{S}$ during the formation of hydrothermal fluids in the reaction zone $[45,46,55]$. This was also observed in the volcanic sulfur sublimate from Kilauea, Hawaii [20] and the Kueishantao native sulfur chimney [42]. By contrast, higher S/Se ratios were reported for molten sulfur from the Lau Basin [19] and native sulfur from the Mariana Arc seafloor hydrothermal system [20].

Significant fractionation between Se and Te is suggested by the Se/Te values for the Kueishantao native sulfur studied here, which are much lower than values for basalts, CI chondrite and pyrolite, although values are still within the range for spinel lherzolite and primitive mantle sulfides (Figure 5). Relative enrichment of these elements can be seen when normalized to $\mathrm{CI}$ chondrite and primitive mantle (Figure 6). The enrichment factor of Te is much higher than that of Se and S, with the latter two showing values of the same magnitude.

$\mathrm{Se}$, Te and S may undergo fractionations due to their distinctive geochemical behaviors during partial melting, although they have a strong geochemical coherence in magmatic-hydrothermal processes $[7,56]$. For example, during mantle melting, sulfur moves most readily into the sulfide melt [2], whereas Te and Se are preferentially retained in the residual mantle, with Te being more compatible than Se $[45,54,57]$. However, a study by Rose-Weston et al. (2009) [54] showed that the addition of 5-10 wt \% S in the metal phase would result in a three-fold enhancement of metal-silicate partitioning of both Se and Te. The ensuing partition coefficiency of Te is greater than that of Se and S in all sulfur-bearing conditions, where Se and S show comparable values over a range of pressures and temperatures. These two processes result in much higher enrichment factors for Se and Te than $S$ in the metallic melt. In addition, Se can partly partition into monosulfide solid solution (mss)-saturated sulfide melt as an anion replacing $\mathrm{S}^{2-}$. By contrast, Te is highly incompatible with mss where it can only be present as neutral metallic species, or as cations in a sulfide melt [2]. Consequently, the relative enrichment of these elements is $\mathrm{Te}>>\mathrm{Se}>\mathrm{S}$ in the metallic melt, also proved by the enrichment factors shown in Figure 6. These volatile elements in the melt will form a vapor phase caused by decompression or diffusion during magma ascent $[7,58]$. When the sulfur-dominated vapor phase ascends to the seafloor, Se and Te are retained and enriched in the native sulfur matrix during cooling from seawater. As a result, fractionation between $S e$ and $T e$ is more obvious than that between $S$ and Se during the Kueishantao hydrothermal circulation. 


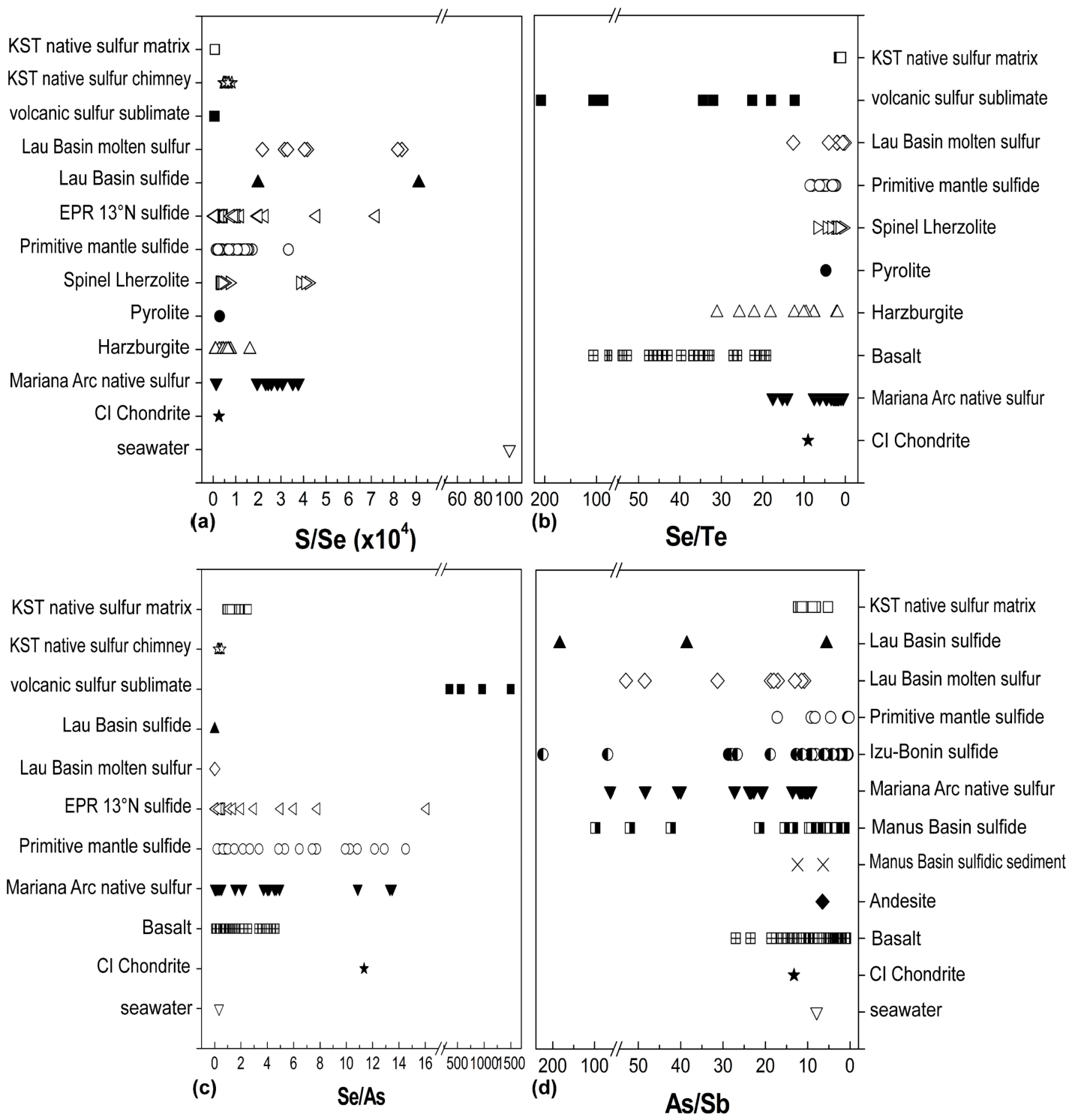

Figure 5. S/Se, Se/Te, Se/As and As/Sb ratios for Kueishantao (KST) native sulfur and other values taken from the literature. (a) Comparison for S/Se ratio; (b) Comparison for Se/Te ratio; (c) Comparison for Se/As ratio; (d) Comparison for As/Sb ratio. $\square$ represents KST native sulfur matrix; is represents

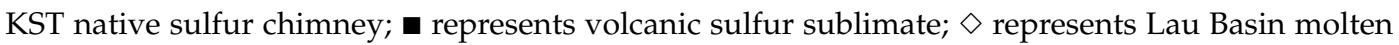
sulfur; $\triangle$ represents Lau Basin sulfide; $\triangleleft$ represents EPR $13^{\circ} \mathrm{N}$ sulfide; $\bigcirc$ represents Primitive mantle sulfide; $\triangleright$ represents Spinel Lherzolite; $\bullet$ represents Pyrolite; $\triangle$ represents Harzburgite; $\mathbf{\nabla}$ represents Mariana Arc native sulfur; $\star$ represents CI chondrite; $\nabla$ represents seawater; $\boxplus$ represents Basalt; - represents Izu-Bonin sulfides; a represents Manus Basin sulfide; $\times$ represents Manus Basin sulfidic sediment; $\diamond$ represents Andesite. Data sources: KST native sulfur matrix (this study); seawater [59]; CI chondrite and pyrolite [4]; volcanic sulfur sublimate [21]; Spinel Lherzolite [5]; EPR $13^{\circ} \mathrm{N}$ sulfide [16]; Lau Basin molten sulfur [19]; Lau Basin sulfide [43]; Harzburgite [3]; Primitive mantle sulfide [45]; KST native sulfur chimney [42]; Basalt [46,60-62]; Andesite [7]; Izu-Bonin sulfides [39]. Mariana Arc native sulfur [20]; Manus Basin sulfide and sulfidic sediment [18].

\subsection{Fractionation of $A s$ and $S b$}

As and $\mathrm{Sb}$ are expected to behave coherently during magmatic-hydrothermal processes due to these elements having the same charges and similar ionic radii $[45,46]$. They are transported to the seafloor via a vapor phase $[7,19,63]$ and their geochemical behaviors during mantle melting could 
help to ascertain controls on their enrichment in the sulfur matrix. It can be seen from Figure $5 \mathrm{c}$ that $\mathrm{Se} /$ As ratios of the Kueishantao sulfur matrix are much lower than that in volcanic sulfur sublimate and CI chondrite, a little higher than Lau Basin molten sulfur and sulfide, and similar to, or within the range of basalts, Mariana arc sulfur, EPR $13^{\circ} \mathrm{N}$ sulfide and the Kueishantao native sulfur chimney. The enrichment factor of As when normalized to primitive mantle is comparable to that of Se (Figure 6), suggesting that Se and As performed coherently during the formation of the sulfur matrix. In addition, As can change its oxidation state so that it can partition into sulfide melts [2].

Antimony is also highly incompatible with mss (cf. Te) and can only be presented as cations, or neutral metallic species during partial melting. Therefore, the sulfur matrix should show higher $\mathrm{Sb}$ enrichment than that of As [4]. However, Figure $5 \mathrm{~d}$ shows higher As/Sb values of the sulfur matrix than that of primitive mantle sulfide, which is contrary to the hypothesis. Meanwhile, the enrichment factor of $\mathrm{Sb}$ when normalized to primitive mantle is significantly lower than that of $\mathrm{Te}$ and As (Figure 6). The relatively low Sb enrichment may be ascribed to the fact that $\mathrm{Sb}$ can convert between +5 and +3 oxidation states during partial melting, where $\mathrm{Sb}^{5+}$ is highly incompatible and $\mathrm{Sb}^{3+}$ is relatively compatible with silicates [46]. The $\mathrm{Sb}$ in this study may be mainly in the +3 valence state and preferentially partitioned into silicates, and thus less likely to enter into the vapor phase when compared to Te. As a result, $\mathrm{Sb}$ shows lower enrichment in the sulfur matrix at Kueishantao.

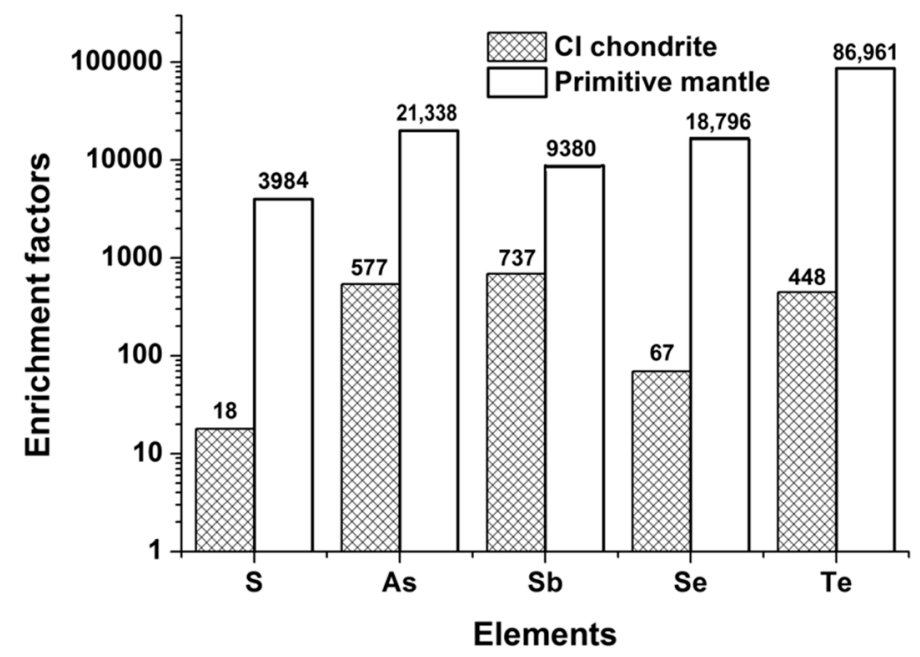

Figure 6. Enrichment factors for $\mathrm{S}, \mathrm{As}, \mathrm{Sb}$, Se and Te compared to $\mathrm{CI}$ chondrite and primitive mantle. Data sources: Kueishantao sulfur matrix (this study); CI chondrite and primitive mantle [4].

\subsection{Formation of Native Sulfur}

Native sulfur has been reported from numerous volcanic/hydrothermal fields such as Poás crater lake [64], Kilauea volcano [21], the Lau basin caldera [19], the Manus basin [18], the Tyrrhenian Sea [65], several submarine arc volcanoes [11,12,28] and sulfur "crater lakes" of the Mariana and Kermadec arcs [20]. Based on the geochemical data measured here and previous studies which suggest a magmatic origin for the sulfur at the Kueishantao hydrothermal area [24,30,66], we propose a possible mechanism for the formation of native sulfur and the enrichment of volatile chalcophile elements in the native sulfur matrix at the Kueishantao hydrothermal area. We suggest that the sulfur mainly originated from the magma chamber beneath Kueishantao with a small contribution of seawater. It did not undergo further fractionation during ascent and precipitation. During partial melting, sulfur tends to partition into sulfide melt [2]. However, the partitioning efficiency of sulfur (and also Se and Te) decreases with falling Fe-O activities [54]. In addition, low degrees of partial melting will enhance the enrichment of incompatible elements in the melt, which can be authenticated by the fact that many arc volcanos discharge enormous amounts of sulfur-rich gases [21,45]. Consequently, sufficient sulfur 
was presented in the metallic melt to form a sulfur-rich vapor phase possibly due to the low $\mathrm{Fe}-\mathrm{O}$ activity and low-degree of partial melting of the mantle beneath the Kueishantao area.

Vapor-transported volatile elements in magmatic gases are potential agents for complexation with metals, especially in sulfur-bearing hydrothermal systems $[60,67,68]$. The enrichment of $\mathrm{Se}, \mathrm{Te}, \mathrm{As}, \mathrm{Sb}$ and $\mathrm{Hg}$ in the Kueishantao sulfur matrix suggests that they experienced gaseous transport [7]. Although $\mathrm{Se}$, As and $\mathrm{Sb}$ were partly partitioned into sulfide during partial melting, residual concentrations of these elements together with $\mathrm{Te}, \mathrm{Hg}$ and superfluous $\mathrm{S}$ will enter into the metallic melt due to their comparable geochemical properties. Subsequently, they fractionated into a vapor phase formed by devolatilization and degassing during magma ascent. At the Kueishantao hydrothermal system, the sulfur-rich vapor phase was transported without further fractionation to the seafloor via magma degassing, which then condensed when mixed with ambient seawater.

\section{Conclusions}

In summary, abundant volatile chalcophile elements $\mathrm{Se}, \mathrm{Te}, \mathrm{As}, \mathrm{Sb}$ and some $\mathrm{Hg}$, were measured in the sulfur matrix of a native sulfur deposit from submarine hydrothermal systems in the Kueishantao area, offshore northeast Taiwan. The Se, Te and As contents are between 750 and $1500 \mathrm{ppm}$, while the $\mathrm{Sb}$ and $\mathrm{Hg}$ contents are around $100 \mathrm{ppm}$ and $40 \mathrm{ppm}$, respectively. The apparent paucity of $\mathrm{Fe}, \mathrm{Cu}$ and other metal elements was observed in the measurement. This could be ascribed to the enrichment of these elements in the sulfur inclusions rather than in the matrix. The $\delta^{34} S$ data $(0.2-2.4 \%$ o) suggest a dual source of sulfur in this hydrothermal deposit: magmatic sulfur leached from the igneous rocks and contribution of seawater sulfate. The large absolute values of Pearson's r (0.512-0.778), as well as the low $P$ value (0.01) shown in Pearson correlation analysis, indicate that $\mathrm{S}, \mathrm{Se}, \mathrm{Te}, \mathrm{As}$ and $\mathrm{Sb}$ display rather coherent behavior during the magmatic and hydrothermal processes. Slight differences in their geochemical behavior during partial melting led to minor fractionation and different degrees of enrichment in the sulfur matrix. Generally, higher incompatible behaviors with both silicate and mss resulted in higher relative enrichment in the sulfur. We believe that vapor transport played a crucial role in the formation of native sulfur and corresponding chalcophile elements in the Kueishantao hydrothermal system. We suggest that during partial melting, volatile chalcophile elements and abundant sulfur were partitioned into a metallic melt and subsequently formed a vapor phase during magma ascent. The sulfur-dominated vapor phase was transported without further fractionation from the magma chamber to the seafloor and then condensed when encountering seawater. Native sulfur deposits were then formed and chalcophile elements were retained in the sulfur matrix.

Author Contributions: Conceptualization, X.-G.C. and D.G.-S.; Data curation, D.G.-S.; Formal analysis, M.-Z.Y. and X.-G.C.; Funding acquisition, X.-G.C. and Y.Y.; Investigation, X.-G.C., D.G.-S. and Y.Y.; Methodology, X.-G.C.; Project administration, X.-G.C.; Resources, C.-T.A.C.; Software, M.-Z.Y. and X.-G.C.; Supervision, D.G.-S.; Validation, D.G.-S.; Visualization, M.-Z.Y.; Writing—original draft, M.-Z.Y. and X.-G.C.; Writing-review \& editing, M.-Z.Y.

Funding: This research was funded by the 973 program "Hydrothermal activity and ore-forming mechanism in back-arc basins" (2013CB429700) and the program for Zhejiang Leading Team of S\&T Innovation (2010R50036).

Acknowledgments: The authors thank the Taiwan Sea-Exploration Company for their support to the sampling of this study and Stephanie Parker from Zhejiang University for her help on the language editing. We are very thankful to the reviewers for their constructive comments which strengthened the manuscript.

Conflicts of Interest: The authors declare no conflict of interest.

\section{References}

1. Goldschmidt, V.M. The principles of distribution of chemical elements in minerals and rocks. The seventh Hugo Muller Lecture, delivered before the Chemical Society on March 17th, 1937. J. Chem. Soc. (Resumed) 1937, 655-673. [CrossRef] 
2. Helmy, H.M.; Ballhaus, C.; Wohlgemuth-Ueberwasser, C.; Fonseca, R.O.C.; Laurenz, V. Partitioning of Se, $\mathrm{As}, \mathrm{Sb}, \mathrm{Te}$ and Bi between monosulfide solid solution and sulfide melt-Application to magmatic sulfide deposits. Geochim. Cosmochim. Acta 2010, 74, 6174-6179. [CrossRef]

3. König, S.; Luguet, A.; Lorand, J.-P.; Wombacher, F.; Lissner, M. Selenium and tellurium systematics of the Earth's mantle from high precision analyses of ultra-depleted orogenic peridotites. Geochim. Cosmochim. Acta 2012, 86, 354-366. [CrossRef]

4. McDonough, W.F.; Sun, S.S. The composition of the Earth. Chem. Geol. 1995, 120, 223-253. [CrossRef]

5. Morgan, J.W. Ultramafic xenoliths: Clues to Earth's late accretionary history. J. Geophys. Res. 1986, 91, 12375-12387. [CrossRef]

6. Aguilera, F.; Layana, S.; Rodríguez-Díaz, A.; González, C.; Cortés, J.; Inostroza, M. Hydrothermal alteration, fumarolic deposits and fluids from Lastarria Volcanic Complex: A multidisciplinary study. Andean Geol. 2016, 43, 166-196. [CrossRef]

7. Shevko, E.P.; Bortnikova, S.B.; Abrosimova, N.A.; Kamenetsky, V.S.; Bortnikova, S.P.; Panin, G.L.; Zelenski, M. Trace Elements and Minerals in Fumarolic Sulfur: The Case of Ebeko Volcano, Kuriles. Geofluids 2018, 2018, 4586363. [CrossRef]

8. Stucker, V.K.; Walker, S.L.; de Ronde, C.E.J.; Tontini, F.C.; Tsuchida, S. Hydrothermal Venting at Hinepuia Submarine Volcano, Kermadec Arc: Understanding Magmatic-Hydrothermal Fluid Chemistry. Geochem. Geophy. Geosyst. 2017, 18, 3646-3661. [CrossRef]

9. Dekov, V.M.; Petersen, S.; Garbe-Schönberg, D.; Kamenov, G.D.; Perner, M.; Kuzmann, E.; Schmidt, M. Fe-Si-oxyhydroxide deposits at a slow-spreading centre with thickened oceanic crust: The Lilliput hydrothermal field (9³3'S, Mid-Atlantic Ridge). Chem. Geol. 2010, 278, 186-200. [CrossRef]

10. Koschinsky, A.; Garbe-Schönberg, C.D.; Sander, S.; Schmidt, K.; Gennerich, H.-H.; Strauss, H. Hydrothermal venting at pressure-temperature conditions above the critical point of seawater, $5^{\circ} \mathrm{S}$ on the Mid-Atlantic Ridge. Geology 2008, 36, 615-618. [CrossRef]

11. De Ronde, C.E.J.; Hannington, M.D.; Stoffers, P.; Wright, I.C.; Ditchburn, R.G.; Reyes, A.G.; Baker, E.T.; Massoth, G.J.; Lupton, J.E.; Walker, S.L.; et al. Evolution of a submarine magmatic- hydrothermal system: Brothers volcano, southern Kermadec arc, New Zealand. Econ. Geol. 2005, 100, 1097-1133. [CrossRef]

12. De Ronde, C.E.J.; Massoth, G.J.; Butterfield, D.A.; Christenson, B.W.; Ishibashi, J.; Ditchburn, R.G.; Hannington, M.D.; Brathwaite, R.L.; Lupton, J.E.; Kamenetsky, V.S.; et al. Submarine hydrothermal activity and gold-rich mineralization at Brothers volcano, Kermadec arc, New Zealand. Miner. Depos. 2011, 46, 541-584. [CrossRef]

13. Lorand, J.-P.; Alard, O. Determination of selenium and tellurium concentrations in Pyrenean peridotites (Ariege, France): New insight into S/Se/Te systematics of the upper in mantle samples. Chem. Geol. 2010, 278, 120-130. [CrossRef]

14. Rouxel, O.; Fouquet, Y.; Ludden, J.N. Subsurface processes at the lucky strike hydrothermal field, Mid-Atlantic ridge: Evidence from sulfur, selenium, and iron isotopes. Geochim. Cosmochim. Acta 2004, 68, 2295-2311. [CrossRef]

15. Berkenbosch, H.A.; de Ronde, C.E.J.; Gemmell, J.B.; McNeill, A.W.; Goemann, K. Mineralogy and formation of black smoker chimneys from Brothers submarine volcano, Kermadec arc. Econ. Geol. 2012, 107, 1613-1633. [CrossRef]

16. Fouquet, Y.; Auclair, G.; Cambon, P.; Etoubleau, J. Geological setting and mineralogical and geochemical investigations on sulfide deposits near $13^{\circ} \mathrm{N}$ on the East Pacific Rise. Mar. Geol. 1988, 84, 145-178. [CrossRef]

17. Fouquet, Y.; Pelleter, E.; Konn, G.; Chazot, G.; Dupré, S.; Alix, A.S.; Chéron, S.; Donval, J.P.; Guyader, V.; Etoubleau, J.; et al. Volcanic and hydrothermal processes in submarine calderas: The Kulo Lasi T example (SW Pacific). Ore Geol. Rev. 2018, 99, 314-343. [CrossRef]

18. Yeats, C.J.; Parr, J.M.; Binns, R.A.; Gemmell, J.B.; Scott, S.D. The SuSu Knolls Hydrothermal Field, Eastern Manus Basin, Papua New Guinea: An Active Submarine High-Sulfidation Copper-Gold System. Econ. Geol. 2014, 109, 2207-2226. [CrossRef]

19. Kim, J.; Lee, K.Y.; Kim, J.H. Metal-bearing molten sulfur collected from a submarine volcano: Implications for vapor transport of metals in seafloor hydrothermal systems. Geology 2011, 39, 351-354. [CrossRef] 
20. De Ronde, C.E.J.; Chadwick, W.W., Jr.; Ditchburn, R.G.; Embley, R.W.; Tunnicliffe, V.; Baker, E.T.; Wallker, S.L.; Ferrini, V.L.; Merle, S.M. Molten Sulfur Lakes of Intraoceanic Arc Volcanoes. In Volcanic Lakes. Advances in Volcanology; Rouwet, D., Christenson, B., Tassi, F., Vandemeulebrouck, J., Eds.; Springer: Berlin/Heidelberg, Germany, 2015; pp. 261-288. ISBN 978-3-642-36832-5.

21. Greenland, L.P.; Aruscavage, P. Volcanic Emission of Se, Te, and as from Kilauea Volcano, Hawaii. J. Volcanol. Geotherm. Res. 1986, 27, 195-201. [CrossRef]

22. Letouzey, J.; Kimura, M. The okinawa trough: Genesis of a back-arc basin developing along a continental margin. Tectonophysics 1986, 125, 209-230. [CrossRef]

23. Chen, Y.G.; Wu, W.S.; Chen, C.H.; Liu, T.K. A date for volcanic eruption inferred from a siltstone xenolith. Quat. Sci. Rev. 2001, 20, 869-873. [CrossRef]

24. Chen, X.G.; Lyu, S.S.; Garbe-Schönberg, D.; Lebrato, M.; Li, X.H.; Zhang, H.Y.; Zhang, P.P.; Chen, C.T.A.; Ye, Y. Heavy metals from Kueishantao shallow-sea hydrothermal vents, offshore northeast Taiwan. J. Mar. Syst. 2018, 180, 211-219. [CrossRef]

25. Chen, C.T.A.; Wang, B.J.; Huang, J.F.; Lou, J.Y.; Kuo, F.W.; Tu, Y.Y.; Tsai, H.S. Investigation into extremely acidic hydrothermal fluids off Kueishan Tao, Taiwan, China. Acta Oceanol. Sin. 2005, 24, 125-133. [CrossRef]

26. Chen, C.T.A.; Zeng, Z.G.; Kuo, F.W.; Yang, T.Y.F.; Wang, B.J.; Tu, Y.Y. Tide-influenced acidic hydrothermal system offshore NE Taiwan. Chem. Geol. 2005, 224, 69-81. [CrossRef]

27. Von Damm, K.L. Seafloor hydrothermal activity-Black smoker chemistry and chimneys. Annu. Rev. Earth Planet. Sci. 1990, 18, 173-204. [CrossRef]

28. Butterfield, D.A.; Nakamura, K.; Takano, B.; Lilley, M.D.; Lupton, J.E.; Resing, J.A.; Roe, K.K. High SO $\mathrm{S}_{2}$ flux, sulfur accumulation, and gas fractionation at an erupting submarine volcano. Geology 2011, 39, 803-806. [CrossRef]

29. Yeats, C.J.; Hollis, S.P.; Halfpenny, A.; Corona, J.C.; LaFlamme, C.; Southam, G.; Fiorentini, M.; Herrington, R.J. Actively forming Kuroko-type volcanic-hosted massive sulfide (VHMS) mineralization at Iheya North, Okinawa Trough, Japan. Ore Geol. Rev. 2017, 84, 20-41. [CrossRef]

30. Zeng, Z.G.; Chen, C.T.A.; Yin, X.B.; Zhang, X.Y.; Wang, X.Y.; Zhang, G.L.; Wang, X.M.; Chen, D.G. Origin of native sulfur ball from the Kueishantao hydrothermal field offshore northeast Taiwan: Evidence from trace and rare earth element composition. J. Asian Earth Sci. 2011, 40, 661-671. [CrossRef]

31. Meyer, B. Solid allotropes of sulfur. Chem. Rev. 1964, 64, 429-451. [CrossRef]

32. Kargel, J.S.; Delmelle, P.; Nash, D.B. Volcanogenic sulfur on Earth and Io: Composition and spectroscopy. Icarus 1999, 142, 249-280. [CrossRef]

33. Chiu, C.L.; Song, S.R.; Hsieh, Y.C.; Chen, C.X. Volcanic characteristics of Kueishantao in northeast Taiwan and their implications. Terr. Atmos. Ocean Sci. 2010, 21, 575-585. [CrossRef]

34. Garbe-Schönberg, D.; Müller, S. Nano-particulate pressed powder tablets for LA-ICP-MS. J. Anal. At. Spectrom. 2014, 29, 990-1000. [CrossRef]

35. Sobolev, A.V.; Asafov, E.V.; Gurenko, A.A.; Arndt, N.T.; Batanova, V.G.; Portnyagin, M.V.; GarbeSchönberg, D.; Krasheninnikov, S.P. Komatiites reveal a hydrous Archaean deep-mantle reservoir. Nature 2016, 531, 628-632. [CrossRef] [PubMed]

36. Garbe-Schönberg, C.D. Simultaneous Determination of Thirty-Seven Trace Elements in Twenty-Eight International Rock Standards by ICP-MS. Geostand. Newsl. 1993, 17, 81-97. [CrossRef]

37. Chen, X.G.; Qiu, Z.Y.; Duan, W.; Li, X.H.; Ye, Y.; Chen, C.T.A. Elemental Enrichment in the Microscopic Inclusions of the Native Sulfur from Kueishantao Hydrothermal System, Taiwan, China. Earth Sci. 2018, 43, 1549-1561. (In Chinese) [CrossRef]

38. Zeng, Z.G.; Liu, C.H.; Chen, C.T.A.; Yin, X.B.; Chen, D.G.; Wang, X.Y.; Wang, X.M.; Zhang, G.L. Origin of a native sulfur chimney in the Kueishantao hydrothermal field, offshore northeast Taiwan. Sci. China Ser. D Earth Sci. 2007, 50, 1746-1753. [CrossRef]

39. Glasby, G.P.; Iizasa, K.; Hannington, M.; Kubota, H.; Notsu, K. Mineralogy and composition of Kuroko deposits from northeastern Honshu and their possible modern analogues from the Izu-Ogasawara (Bonin) Arc south of Japan: Implications for mode of formation. Ore Geol. Rev. 2008, 34, 547-560. [CrossRef]

40. Liu, C.H.; Wang, X.M.; Zeng, Z.G.; Yin, X.B.; Chen, C.T.A.; Zhang, S.W. Origin of the hydrothermal fluid of the shallow sea near Kueishantao Island. Mar. Sci. 2010, 34, 61-68. (In Chinese)

41. Rees, C.E.; Jenkins, W.J.; Monster, J. The sulfur isotopic composition of ocean water sulfate. Geochim. Cosmochim. Acta 1978, 42, 377-381. [CrossRef] 
42. Liu, C.H.; Fu, Z.H.; Yin, X.B. The seawater influence on sulfur isotopic evolution within modern seafloor hydrothermal chimneys. Mar. Sci. 2006, 30, 90-93. (In Chinese)

43. Fouquet, Y.; Vonstackelberg, U.; Charlou, J.L.; Donval, J.P.; Erzinger, J.; Herzig, P.; Muhe, R.; Wiedicke, M.; Soakai, S.; Whitechurch, H. Hydrothermal activity in the lau back-arc basin-sulfides and water chemistry. Geology 1991, 19, 303-306. [CrossRef]

44. Fulignati, P.; Sbrana, A. Presence of native gold and tellurium in the active high-sulfidation hydrothermal system of the La Fossa volcano (Vulcano, Italy). J. Volcanol. Geotherm. Res. 1998, 86, 187-198. [CrossRef]

45. Hattori, K.H.; Arai, S.; Clarke, D.B. Selenium, tellurium, arsenic and antimony contents of primary mantle sulfides. Can. Mineral. 2002, 40,637-650. [CrossRef]

46. Hertogen, J.; Janssens, M.J.; Palme, H. Trace elements in ocean ridge basalt glasses: Implications for fractionations during mantle evolution and petrogenesis. Geochim. Cosmochim. Acta 1980, 44, 2125-2143. [CrossRef]

47. Sakai, H.; Des Marais, D.J.; Ueda, A.; Moore, J.G. Concentrations and isotope ratios of carbon, nitrogen and sulfur in ocean-floor basalts. Geochim. Cosmochim. Acta 1984, 48, 2433-2441. [CrossRef]

48. Shanks, W.C. Stable isotopes in seafloor hydrothermal systems: Vent fluids, hydrothermal deposits, hydrothermal alteration, and microbial processes. Rev. Mineral. Geochem. 2001, 43, 469-525. [CrossRef]

49. Giggenbach, W.F. Redox potential governing the chemistry of fumarolic gas discharges from White Island, New Zealand. Appl. Geochem. 1987, 2, 143-161. [CrossRef]

50. Zhang, H.Y.; Yang, T.F.; Chen, C.T.A.; Chen, X.G.; Qin, H.W.; Jin, A.M.; Ding, Q.; Pan, Y.W.; Xia, M.S.; Ye, Y. Gas composition of submarine hydrothermal systems off Guishandao and in coastal hot springs off Lüdao in Taiwan. J. Trop. Oceanogr. 2013, 32, 50-57. (In Chinese) [CrossRef]

51. Janecky, D.R.; Shanks, W.C. Computational modeling of chemical and sulfur isotopic reaction processes in seafloor hydrothermal systems: Chimneys, massive sulfides, and subjacent alteration zones. Can. Mineral. 1988, 26, 805-825.

52. Rodgers, J.L.; Nicewander, W.A. Thirteen Ways to Look at the Correlation Coefficient. Am. Stat. 1988, 42, 59-66. [CrossRef]

53. Barrett, T.J.; Joseph, E.P. Extreme alteration in an acid-sulphate geothermal field: Sulphur Springs, Saint Lucia. Chem. Geol. 2018, 500, 103-135. [CrossRef]

54. Rose-Weston, L.; Brenan, J.M.; Fei, Y.; Secco, R.A.; Frost, D.J. Effect of pressure, temperature, and oxygen fugacity on the metal-silicate partitioning of Te, Se, and S: Implications for earth differentiation. Geochim. Cosmochim. Acta 2009, 73, 4598-4615. [CrossRef]

55. Floor, G.H.; Román-Ross, G. Selenium in volcanic environments: A review. Appl. Geochem. 2012, 27, 517-531. [CrossRef]

56. Keith, M.; Smith, D.J.; Jenkin, G.R.T.; Holwell, D.A.; Dye, M.D. A review of Te and Se systematics in hydrothermal pyrite from precious metal deposits: Insights into ore-forming processes. Ore Geol. Rev. 2018, 96, 269-282. [CrossRef]

57. Fornadel, A.P.; Spry, P.G.; Haghnegahdar, M.A.; Schauble, E.A.; Jackson, S.E.; Mills, S.J. Stable Te isotope fractionation in tellurium-bearing minerals from precious metal hydrothermal ore deposits. Geochim. Cosmochim. Acta 2017, 202, 215-230. [CrossRef]

58. Sparks, R.S.J. Dynamics of magma degassing. Geol. Soc. Lond. Spec. Publ. 2003, 213, 5-22. [CrossRef]

59. Wright, J.; Colling, A. Seawater: Its Composition Properties and Behaviour, 2nd ed.; Bearman, G., Ed.; Butterworth-Heinmann: Oxford, UK, 1989; ISBN 978-1-4832-5707-5.

60. Lissner, M.; Konig, S.; Luguet, A.; le Roux, P.J.; Schuth, S.; Heuser, A.; le Roex, A.P. Selenium and tellurium systematics in MORBs from the southern Mid-Atlantic Ridge (47-50S). Geochim. Cosmochim. Acta 2014, 144, 379-402. [CrossRef]

61. Jenner, F.E.; O'Neill, H.S. Analysis of 60 elements in 616 ocean floor basaltic glasses. Geochem. Geophy. Geos. 2012, 13, Q02005. [CrossRef]

62. Yang, S.Y.; Humayun, M.; Salters, V.J.M. Elemental Systematics in MORB Glasses from the Mid-Atlantic Ridge. Geochem. Geophy. Geos. 2018, 19, 4236-4259. [CrossRef]

63. Williams-Jones, A.E.; Heinrich, C.A. Vapor transport of metals and the formation of magmatic-hydrothermal ore deposits. Econ. Geol. 2005, 100, 1287-1312. [CrossRef]

64. Oppenheimer, C.; Stevenson, D. Liquid sulfur lakes at Poas volcano. Nature 1989, 342, 790-793. [CrossRef] 
65. Peters, M.; Strauss, H.; Petersen, S.; Kummer, N.-A.; Thomazo, C. Hydrothermalism in the Tyrrhenian Sea: Inorganic and microbial sulfur cycling as revealed by geochemical and multiple sulfur isotope data. Chem. Geol. 2011, 280, 217-231. [CrossRef]

66. Kuo, F.W. Preliminary Investigation of the Hydrothermal Activities off Kueishantao Island. Master's Thesis, National Sun Yat-sen University, Kaohsiung, Taiwan, 2011. (In Chinese).

67. McPhail, D.C. Thermodynamic properties of aqueous tellurium species between 25 and $350^{\circ} \mathrm{C}$. Geochim. Cosmochim. Acta 1995, 59, 851-866. [CrossRef]

68. Seo, J.H.; Guillong, M.; Heinrich, C.A. The role of sulfur in the formation of magmatic-hydrothermal copper-gold deposits. Earth Planet. Sci. Lett. 2009, 282, 323-328. [CrossRef]

(C) 2019 by the authors. Licensee MDPI, Basel, Switzerland. This article is an open access article distributed under the terms and conditions of the Creative Commons Attribution (CC BY) license (http://creativecommons.org/licenses/by/4.0/). 